\title{
Expression of HIF-1a and HIF-2a correlates to biological and clinical significance in papillary thyroid carcinoma
}

\author{
Yan-Mei Liu', Shen-Peng Ying ${ }^{1}$, Ying-Rui Huang ${ }^{2}$, Yin Pan ${ }^{3}$, Wei-Jun Chen ${ }^{1}$, Ling-Qin Ni ${ }^{1}$, Jin-Ye Xu \\ Qin-Yan Shen ${ }^{5}$ and Yong Liang ${ }^{2,6^{*}}$
}

\begin{abstract}
Background: The aim of this study was to detect the expression of hypoxia-inducible factor (HIF)-1a and HIF-2a in papillary thyroid carcinoma (PTC) compared with normal thyroid tissues.

Methods: The mRNA levels and protein levels of HIF-1a and HIF-2a were detected by real-time PCR and Western blot separately in 30 pairs of PTCs and normal thyroid cases. The protein levels were also detected by immunohistochemistry (IHC) using 92 samples of PTC group and 46 normal samples as control group for analyzing the biological and clinical significance of the expression of HIF-1a/HIF-2a.

Results: Real-time PCR results showed the mRNA level of HIF-1a and HIF-2a were significantly higher in PTC than normal group $(P<0.001)$. Also, significantly higher positive rates $(73 \% / 65 \%)$ of HIF-1a and HIF-2a were observed in PTC compared with the control group $(27 \% / 35 \%)$ by IHC $(P<0.01)$; the consistent results were gotten with Western blot. Although we did not find a significant correlation between the expression of HIF-1a and HIF-2a with gender, age, calcification, or Hashimoto's disease in the present study $(P>0.05)$, both of their expressions were correlated to lymph node metastasis $(P<0.05)$, capsular invasion $(P<0.05)$, and TNM stage $(P<0.05)$.

Conclusions: Overexpression of HIF-1a and HIF-2 $a$ are associated with the carcinogenesis of PTC, served as potential biomarkers of PTC.
\end{abstract}

Keywords: HIF-1a, HIF-2a, RT-PCR, IHC, Western blot

\section{Background}

As one of the most common endocrine tumor, thyroid cancer has become the fifth highest incidence of malignant tumor among American women [1]. The incidence of thyroid cancer, especially papillary thyroid carcinoma (PTC), was increased constantly over the recent years at a remarkable rate, averaging almost $4 \%$ per year [2]. About 60,220 new cases were reported in 2013 [3] which have attracted much attention.

The PTC shows some special biological behaviors, such as it is easily accompanied with calcification or cystic in the development of tumor although the volume

\footnotetext{
* Correspondence: liangytu@aliyun.com

Yan-Mei Liu and Shen-Peng Ying share co-first authorship.

${ }^{2}$ Taizhou University, Taizhou 318000, Zhejiang, China

${ }^{6}$ Department of The First Affiliated Hospital of Wenzhou Medical University, Wenzhou 325000, Zhejiang, China

Full list of author information is available at the end of the article
}

is small, and it is easily accompanied with lymph node metastasis (LNM) [4]. As we know, tumor growth requires the presence of a local vascular network that supplies both oxygen and nutrients to tumor cells. And most tumor cells have adapted to and can grow in a hypoxic condition. Such hypoxic zones have been postulated to increase patient treatment resistance and favor tumor progression $[5,6]$.

Hypoxia-inducible factor (HIF), known as a heterodimer transcription factor consisting of an oxygensensitive alpha subunit (HIF- $\alpha$ ) and a constitutive beta subunit (HIF- $\beta$ ) [7], is closely associated with the formation of hypoxic microenvironment [8]. Under hypoxia, HIF- $\alpha$ subunits are stabilized and translocated to the nucleus where they heterodimerize with arylhydrocarbon receptor nuclear translocator (ARNT) and bind to hypoxia response elements (HREs) located within 
regulatory elements of HIF target genes. There are three types of HIF- $\alpha$ subunits, HIF- $1 \alpha$, HIF- $2 \alpha$, and HIF- $3 \alpha$, and at present, the HIF- $1 \alpha$ and HIF- $2 \alpha$ gained more attention [9-12]. Although it has been reported that HIF is associated with tumorigenesis [13] or radiosensitivity [14], reports on how HIF- $1 \alpha$ and HIF- $2 \alpha$ affect the oncogenesis showed inconsistent results $[15,16]$. And overexpression of HIF- $1 \alpha$ and HIF- $2 \alpha$ correlated with different kinds of cancers, respectively $[17,18]$.

Thus, the aim of this study was to investigate the expression of HIF- $1 \alpha$ and HIF- $2 \alpha$ in papillary thyroid carcinoma and its roles in the development of PTC.

\section{Methods}

\section{Patients and specimens}

All the materials were obtained with agreement of patients and signed the informed consent. The usage of human materials for analysis was approved by the local ethical committee. All PTCs were staged according to the International Union Against Cancer (UICC) 2009 guidelines [19]. Ninety-two samples of PTC group (age range from 23 to 72 years, 58 male and 34 female) and control group (46 cases total, age range from 21 to 76 years, 19 male and 27 female) were collected from patients who underwent surgical resection at the Department of Tai Zhou Central Hospital between January to October in 2013, and the control samples were relatively normal tissues from the nodular goiters. All cases were confirmed by pathologists and divided into nine groups by age, sex, tumor size, etc. All tissue samples were obtained from the patients prior to any medical treatment.

\section{RNA extraction and first-strand CDNA synthesis}

Of each sample, 50- to 100-mg tissues from 30 fresh frozen tumors and normal tissues, respectively, were used to isolate total RNA with TRIzol reagent (Invitrogen, Camarillo, CA, USA). All the processes of RNA extraction were done on ice, and all the workers wear masks and gloves to prevent the degradation of RNA. The amount and quality of the extracted RNA were determined by the Nano Drop Spectrophotometer (Thermo Scientific, Wilmington, DE, USA). The cDNA synthesis was performed under the condition of $37^{\circ} \mathrm{C}$ for $60 \mathrm{~min}$ in a volume of $20 \mu \mathrm{L}$ containing $2 \mu \mathrm{L}$ RNA, $2 \mu \mathrm{L} 10 \times \mathrm{RT}$ mix, $2 \mu \mathrm{L}$ dNTP, $2 \mu \mathrm{L}$ Oligo-dT15, $1 \mu \mathrm{L}$ Quant Reverse Transcriptase, and $11 \mu \mathrm{L}$ RNase-free $d_{d d} \mathrm{H}_{2} \mathrm{O}$ in reaction buffer.

\section{Real-time polymerase chain reaction}

The primer sequences used herein were HIF- $1 \alpha$ forward 5'-ACTTCTGGATGCTGGTGATTTG-3', reverse 5'GCTTCGCTGTGTGTTTTGTTCT-3'; HIF-2 $\alpha$ forward $5^{\prime}$-TCATGCGACTGGCAATCAGC-3', reverse $5^{\prime}$-GTC ACCACGGCAATGAAACC-3'; and glyceraldehyde-3- phosphate dehydrogenase (GAPDH) forward 5'-CAAA GCTGGTGTGGGAGG-3', reverse 5'-CTCCTGGAAG ATGGTGATGG-3'. SYBR Green mix, cDNA template, $0.3 \mu \mathrm{L}$ forward primer, $0.3 \mu \mathrm{L}$ reverse primer, and $\mathrm{ddH}_{2} \mathrm{O}$ were added into the reaction system ( $20 \mu \mathrm{L}$ total volume). All samples were amplified using the following standard PCR system: $95{ }^{\circ} \mathrm{C}$ pre-degeneration for $2 \mathrm{~min}, 95{ }^{\circ} \mathrm{C}$ degeneration for $15 \mathrm{~s}, 60^{\circ} \mathrm{C}$ annealing for $30 \mathrm{~s}$, and $68^{\circ} \mathrm{C}$ extension for $60 \mathrm{~s}$ within 40 circulations. After reactions were completed, baseline and threshold were adjusted in the ABI 7500 software system (Applied Biosystem, USA) where the cycle threshold (CT) value of each reaction hole was read. This reaction has been repeated for three times. Data were analyzed according to the comparative CT value method and were normalized according to the GAPDH expression in each sample.

\section{Immunohistochemical analysis}

One representative paraffin-embedded block from each case was selected and sectioned serially at $4 \mu \mathrm{m}$. Slides were baked at $68{ }^{\circ} \mathrm{C}$ for $2 \mathrm{~h}$ and soaked in xylene; antigen retrieval was performed by boiling the slides with citrate puffer $(\mathrm{pH}=6)$ at $95{ }^{\circ} \mathrm{C}$, then blocked by normal goat serum. The samples were incubated with an antibody against HIF- $1 \alpha$ (1:100; rabbit monoclonal, clone; ab51608; Abcam; USA) and HIF-2 $\alpha$ (1:250; rabbit monoclonal, clone; ab20654; Abcam; USA) in an automatic immunostainer and kept at $4{ }^{\circ} \mathrm{C}$ overnight. Then, the immunostainer was put in $37^{\circ} \mathrm{C}$ for $60 \mathrm{~min}$ before a secondary antibody (ZB-2010; Zhongshan Golden Bridge Biotechnology, China) was added, and then treated with DAB (diaminobenzidine) for $2 \mathrm{~min}$. The sections were investigated using a multiheaded microscope by two investigators who were blinded to the patients' clinical information.

Stromal staining of HIF expression was graded semiquantitatively as follows: I, no stromal staining; II, little, staining in $<10 \%$ of stroma; III, moderate, staining in $\geq 10$ and $\leq 50 \%$; IV, strong, staining in $>50 \%$ of stroma. For statistical analysis, a final staining score of I or II was combined into the low expression group, and a final staining score of III or IV was combined in the high expression group.

\section{Protein preparation and Western blotting analysis}

Of each sample, 50- to 100-mg tissues from 30 fresh frozen tumors and normal tissues were minced on the ice and sonicated in protein lysis buffer. Then, the protein was collected by centrifuging at 10,000-14,000 rpm for $5 \mathrm{~min}$; total of $30-50 \mathrm{mg}$ of protein from each case was loaded on $10 \%$ SDS polyacrylamide gels and separated by SDS-PAGE, then transferred to PVDF membranes. After blocking with $5 \%$ non-fat milk in TBS-T for $1.5 \mathrm{~h}$, the membranes were treated with the primary antibodies 

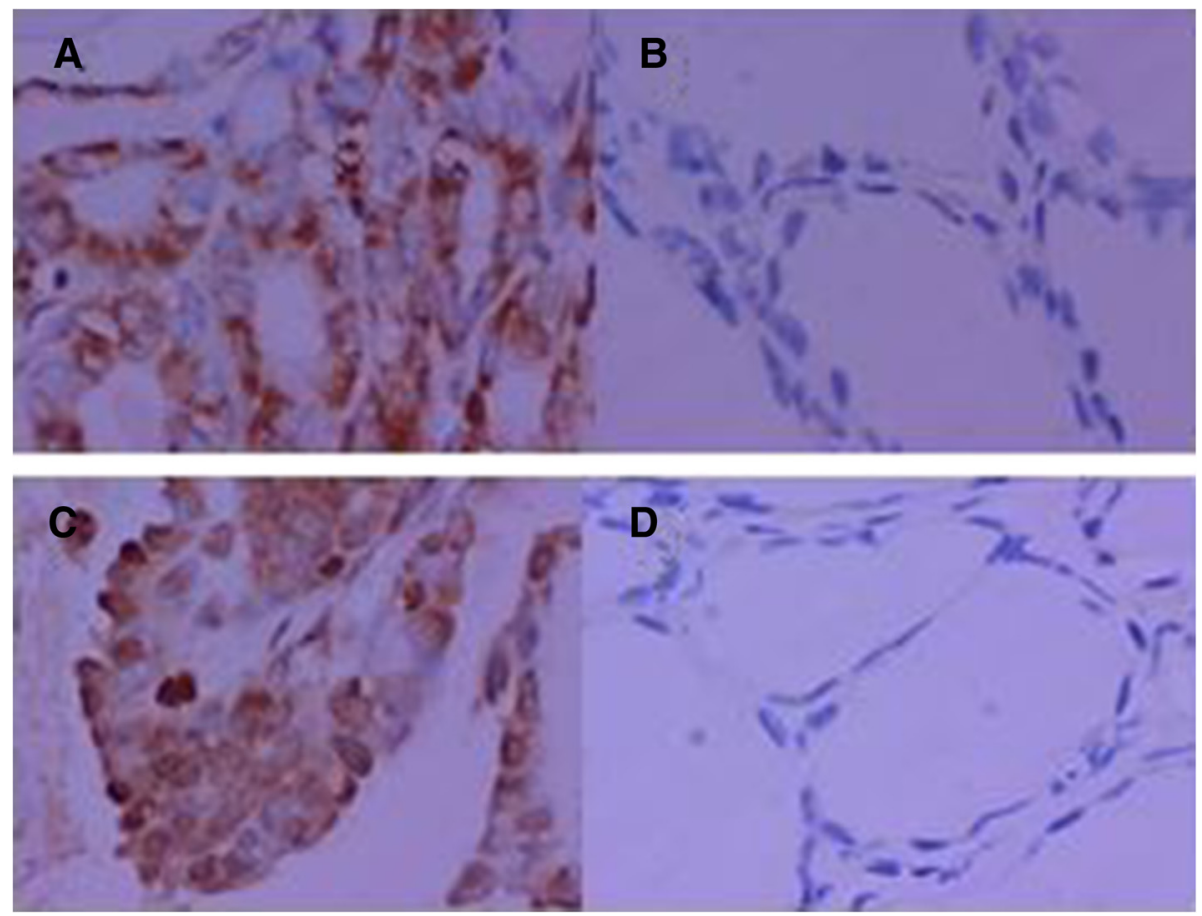

Fig. 1 Hypoxia-inducible factor in a papillary thyroid carcinoma. a Representative images of HIF-1a in PTC. b Representative images of HIF-1a in normal. c Representative images of HIF-2a in PTC. $\mathbf{d}$ Representative images of HIF- $2 a$ in normal; $\times 400$

of HIF-1 $\alpha$ (1:1000; Abcam; USA), HIF-2 $\alpha$ (1:1000; Abcam; USA), and $\beta$-actin (1: 3000, Abcam; USA) for $1.5 \mathrm{~h}$ at $37{ }^{\circ} \mathrm{C}$, and then kept the membrane at $4{ }^{\circ} \mathrm{C}$ overnight. After that, the membranes were incubated with the secondary antibody at an appropriate concentration for $1.5 \mathrm{~h}$. The bands were visualized using an enhanced chemiluminescence detection system.

\section{Statistical analysis}

Statistical analysis was performed by SPSS 17.0 (SPSS Inc., Chicago, IL, USA) statistical software. Continuous variables were expressed as a mean with standard deviation and analyzed using Student's $t$ test (two-tailed). Comparison of the clinicopathological parameters with HIF- $1 \alpha$ and HIF- $2 \alpha$ expression between the tumor and normal tissues was conducted by the two-tailed chisquare test. The correlation between the expression of HIF- $1 \alpha$ and HIF- $2 \alpha$ was detected by Spearman rank. $P$ value $<0.05$ was considered to be statistically significant.

\section{Results}

\section{Immunohistochemistry expression of HIF-1a and HIF-2a} in PTC

The protein levels of HIF- $1 \alpha$ and HIF- $2 \alpha$ were first measured by immunohistochemistry (IHC) on paraffin slides of 92 samples of PTC and paired 46 relatively normal tissues. The positive staining of HIF-1 $\alpha$ was located in the cytoplasm and the nuclei, but the unequivocal
HIF- $2 \alpha$ staining was observed mainly in the cytoplasm (Fig. 1). Overexpression of HIF-1 $\alpha$ was found in 67 (73\%) of tumor tissues and in 11 (27\%) of the normal group. In consistence, high expression of HIF- $2 \alpha$ was also found in 60 (65\%) of tumor tissues, compared with 15 (35\%) of the other group. The differences in HIF- $1 \alpha$ and HIF- $2 \alpha$ protein expression between PTCs and normal tissues were statistically significant $(P<0.01)$ (Table 1$)$.

\section{Western blot expression of HIF-1 $a$ and HIF-2 $a$ in PTC}

To explore the expression of HIF- $1 \alpha$ and HIF- $2 \alpha$ in PTC, Western blot was also applied to detect the protein levels of them in four paired PTC specimens. As shown in Fig. 2, the protein level of HIF-1 $\alpha$ in PTC tissues was significantly higher than that in control tissues, the same as HIF- $2 \alpha$.

\section{Correlations of HIF-1 $a$ and HIF-2 $a$ protein expression with clinicopathological parameters}

Significant correlations of HIF- $1 \alpha$ and HIF- $2 \alpha$ expression with clinicopathological parameters are listed in

Table 1 Immunohistochemistry results

\begin{tabular}{|c|c|c|c|c|c|c|c|c|}
\hline \multirow[t]{2}{*}{ Team } & \multicolumn{2}{|c|}{ HIF-1a } & \multirow[t]{2}{*}{$\chi^{2}$} & \multirow[t]{2}{*}{$P$ value } & \multicolumn{2}{|c|}{ HIF-2a } & \multirow[t]{2}{*}{$\chi^{2}$} & \multirow[t]{2}{*}{$P$ value } \\
\hline & High & Low & & & High & Low & & \\
\hline Tumor & 67 & 25 & & & 60 & 32 & & \\
\hline Normal & 11 & 35 & 29.86 & $<0.01$ & 15 & 31 & 13.14 & $<0.01$ \\
\hline
\end{tabular}




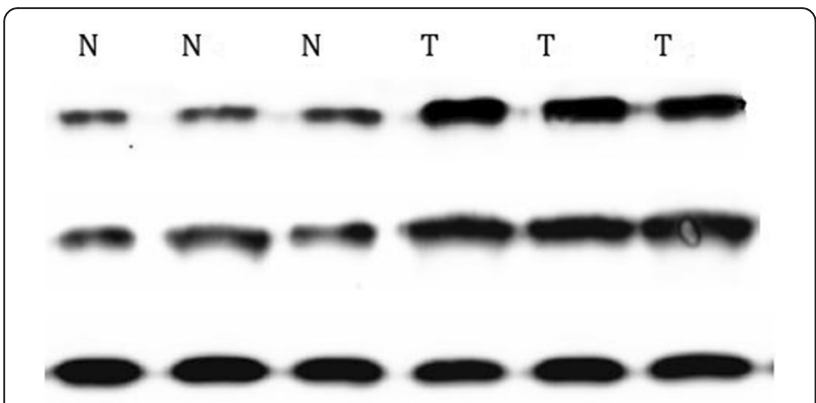

Fig. 2 The expression of HIF-1a and HIF-2a protein in PTC tissue and the paired normal tissue was confirmed by Western blotting. Beta-actin was applied as a control. $N$ normal, $T$ tumor

Table 2. Regarding the clinical data, no gender-specific distribution was found both in HIF- $1 \alpha(P=0.223)$ and HIF- $2 \alpha \quad(P=0.725)$.There were also no specific differences in HIF- $1 \alpha$ and HIF- $2 \alpha$ protein expression between older $(>45)$ and younger $(\leq 45)$ patients $(P=0.882$, $P=0.675)$. Both calcification and Hashimoto's disease of the PTC showed no significant correlation with HIF- $1 \alpha$ $(P=0.230 ; P=0.410)$ and HIF- $2 \alpha$ expression $(P=0.463$; $P=0.256)$.

Correlation of expression of HIF- $1 \alpha$ in PTC tissues was not seen between the larger $(\geq 1)$ and smaller $(<1)$ tumor size $(P=0.782)$; however, significant differences were observed in HIF-2 $\alpha$ expression $(P=0.043)$. Additionally, chi-square test showed a significant association between the presence of lymph node metastasis with HIF- $1 \alpha$ $(P=0.006)$ and HIF- $2 \alpha$ expression $(P=0.037)$.There was also a statistical significance between capsular invasion with the expression of HIF- $1 \alpha(P=0.012)$ and HIF- $2 \alpha$ $(P=0.004)$. Generally, patients with unequivocal HIF- $1 \alpha$ and HIF- $2 \alpha$ staining exhibited a higher incidence of capsular invasion than patients with negative or equivocal HIF- $1 \alpha$ and HIF- $2 \alpha$ expression. Patients with high HIF- $1 \alpha$ staining exhibited a higher TNM stage than patients with low HIF- $1 \alpha$ expression $(P=0.021)$, the same as HIF- $2 \alpha$ $(P=0.009)$.

\section{mRNA expression of HIF-1 $a$ and HIF-2 $a$ in PTCs}

The mRNA levels of HIF- $1 \alpha$ and HIF- $2 \alpha$ were showed in Fig. 3. The relative expression of HIF- $1 \alpha$ mRNA in PTC was $1.9948 \pm 0.3952$, and significant differences were observed $(t=13.784, P<0.001)$; the HIF- $2 \alpha$ mRNA was $1.5691 \pm 0.3889$, which is apparently higher than the normal. $(t=5.237, P<0.001)$. According to these results, it is clearly showed that both mRNA and protein expression levels of HIF- $1 \alpha$ and HIF-2 $\alpha$ were higher in PTCs than the paired normal tissues.

\section{The correlation of HIF-1 $\alpha$ and HIF-2 $\alpha$ expression}

The correlation of HIF- $1 \alpha$ and HIF- $2 \alpha$ protein expression was assessed by Spearman rank test. As shown in
Table 2 Correlation of clinicopathological/morphological parameters and HIF-1a/HIF-2a expression

\begin{tabular}{|c|c|c|c|c|c|}
\hline \multirow{4}{*}{$\begin{array}{l}\text { Clinical } \\
\text { Characteristics }\end{array}$} & PTC & HIF-1a & & HIF-2a & \\
\hline & Total & $(+)$ & & $(+)$ & \\
\hline & $n(\%)$ & $n(\%)$ & & $n(\%)$ & \\
\hline & $92(100 \%)$ & 67 (73 \%) & $P$ value & $60(65 \%)$ & $P$ value \\
\hline \multicolumn{6}{|l|}{ Gender } \\
\hline Female & $64(70)$ & $49(67)$ & & $41(64)$ & \\
\hline Male & $28(30)$ & $18(64)$ & 0.223 & $19(68)$ & 0.725 \\
\hline \multicolumn{6}{|l|}{ Age (year) } \\
\hline$\geq 45$ & $49(53)$ & $36(74)$ & & $31(63)$ & \\
\hline$<45$ & $43(47)$ & $31(72)$ & 0.882 & $29(67)$ & 0.675 \\
\hline \multicolumn{6}{|l|}{ Tumor size $(\mathrm{cm})$} \\
\hline$\geq 1$ & $42(40)$ & $30(71)$ & & $32(76)$ & \\
\hline$<1$ & $50(60)$ & $37(74)$ & 0.782 & $28(56)$ & $0.043^{*}$ \\
\hline \multicolumn{6}{|l|}{$\begin{array}{l}\text { Lymph node } \\
\text { metastasis }\end{array}$} \\
\hline Yes & $51(55)$ & $43(84)$ & & $38(75)$ & \\
\hline No & $41(45)$ & $24(59)$ & $0.006^{*}$ & $22(54)$ & $0.037^{*}$ \\
\hline \multicolumn{6}{|l|}{ Calcification } \\
\hline Yes & 35 (38) & $23(66)$ & & $21(60)$ & \\
\hline No & $57(62)$ & $44(77)$ & 0.230 & $39(68)$ & 0.410 \\
\hline \multicolumn{6}{|c|}{ Capsular invasion } \\
\hline Yes & $56(61)$ & $46(82)$ & & $43(77)$ & \\
\hline No & $36(39)$ & $21(58)$ & $0.012^{*}$ & $17(47)$ & $0.004^{*}$ \\
\hline \multicolumn{6}{|l|}{ TNM stage } \\
\hline$|-| \mid$ & $52(59)$ & $33(64)$ & & $28(51)$ & \\
\hline III-IV & $40(41)$ & $34(85)$ & $0.021^{*}$ & $32(77)$ & $0.009^{*}$ \\
\hline \multicolumn{6}{|l|}{$\begin{array}{l}\text { Hashimoto's } \\
\text { disease }\end{array}$} \\
\hline Yes & $62(67)$ & $47(76)$ & & $38(61)$ & \\
\hline No & $30(33)$ & $20(67)$ & 0.463 & $22(73)$ & 0.256 \\
\hline
\end{tabular}

Table 3. Forty-eight (52 \%) PTCs displayed high expression, and $13(14 \%)$ showed low expression for both HIF- $1 \alpha$ and HIF- $2 \alpha$. The correlation between them was statistically significant $\left(r_{\mathrm{s}}=0.221, P=0.034\right)$.

\section{Discussion}

Hypoxia is a common condition found in a range of solid tumors and has been increasingly recognized to play a key role in different stages of tumor progression [20]. The adaptation of tumor to hypoxia is predominantly regulated by HIF- $1 \alpha$ and HIF- $2 \alpha$; while highly homologous, HIF- $1 \alpha$ and HIF- $2 \alpha$ have unique tissue distributions and play critical but non-overlapping roles in tumor progression [21]. HIF-1 $\alpha$ has been implicated as a tumor promoter, while it has been suggested that HIF- $2 \alpha$ 


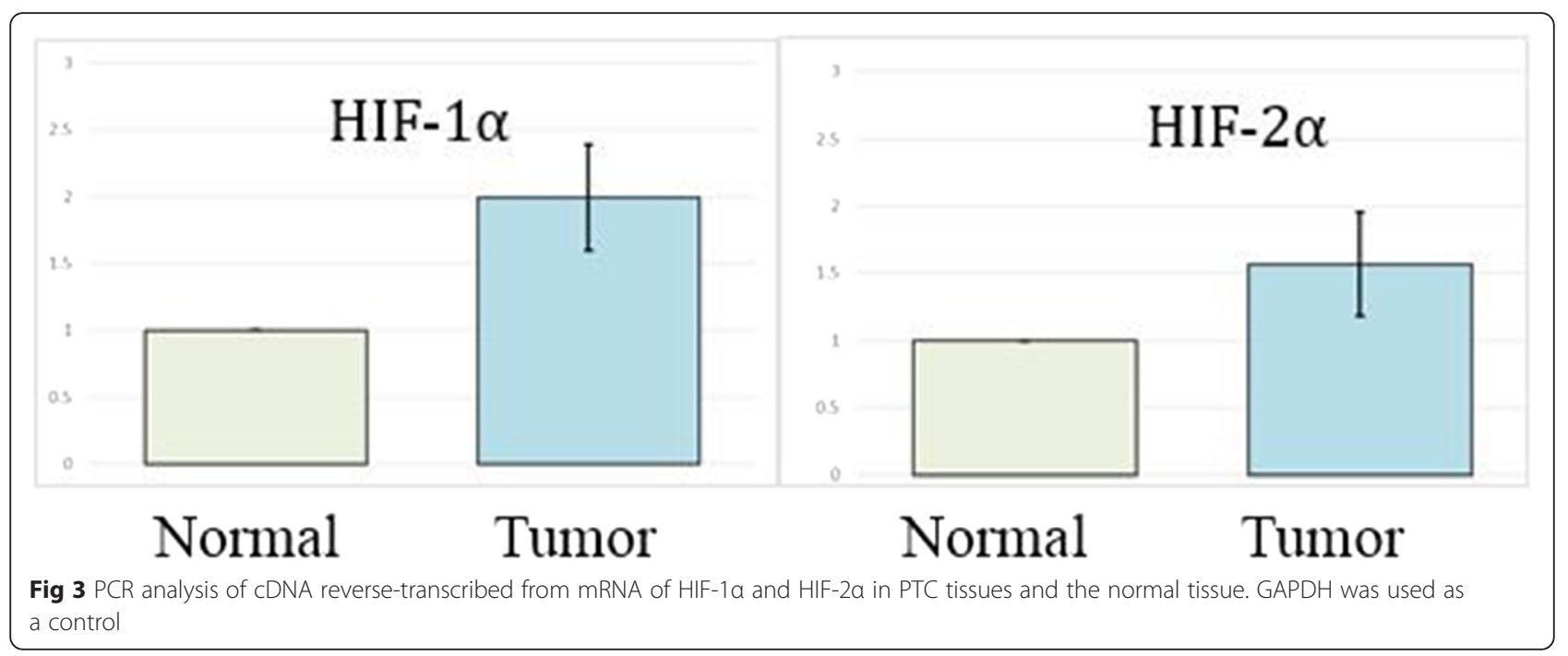

act as a tumor suppressor gene [22]. To date, studies have observed that HIF- $1 \alpha$ and HIF- $2 \alpha$ are overexpressed in several human tumors, such as ovarian, esophageal, head and neck [26], breast, prostate, bladder, and oral epithelium [23-26]. Moreover, there have been several studies which respectively showed that HIF-1 $\alpha$ [27] and HIF- $2 \alpha$ [28] are both upregulated in thyroid carcinoma compared with normal thyroid or benign lesion. However, no studies have examined the expression of HIF- $1 \alpha$ and HIF- $2 \alpha$ under the same condition and systematically assessed the correlation of their expression with clinicopathological features in PTC simultaneously. In the present study, we observed that an overexpression of HIF- $1 \alpha$ and HIF- $2 \alpha$ is present in a majority of PTC compared to normal tissues.

As the first HIF family member [29, 30], HIF-1 is an important transcription factor in the development of several tumors. HIF- $2 \alpha$, a gene with high construction gene similarity with HIF- $1 \alpha$, contains $48 \%$ the same basic amino acid sequences, basic helix-loop-helix (bHLH) area with $83 \%$ similarity, and per-amt-sim (PAS) area with $70 \%$ similarity. Recent studies of HIF- $2 \alpha$ failed to show consistent results on how HIF- $1 \alpha$ and HIF- $2 \alpha$ affect the PTC development [31-33]. Our results demonstrated that the positive rate of HIF- $1 \alpha$ and HIF- $2 \alpha$ in PTCs was $67(73 \%)$ and 60 (65\%) higher than those in normal thyroid, respectively $(P<0.01)$, which indicated overexpression of HIF- $1 \alpha$ and HIF-2 $\alpha$ in PTCs, which was confirmed by real-time PCR and Western blot.

Table 3 Correlation of HIF-1a and HIF-2a protein expression

\begin{tabular}{lllll}
\hline & HIF-2a & & $r_{5}$ & $P$ \\
\cline { 2 - 3 } HIF-1a & High & Low & & \\
\hline High & 48 & 19 & 0.221 & 0.034 \\
Low & 12 & 13 & & \\
\hline
\end{tabular}

The correlation of HIF- $1 \alpha$ protein expression with several clinicopathological parameters was also assessed. We found that HIF- $1 \alpha$ and HIF- $2 \alpha$ protein expression was not associated with gender, age, tumor size, calcification, and Hashimoto's disease. However, there was a significant correlation of HIF-1 $\alpha$ protein expression relative to TNM stage $(P=0.021)$ and LNM $(P=0.006)$. The overexpression of HIF- $1 \alpha$ was associated with capsular invasion and high TNM stage and LNM. These results suggested that HIF- $1 \alpha$ may play an important role in invasion, metastasis, and progression of PTC. The same with HIF- $1 \alpha$, HIF- $2 \alpha$ protein expression was not associated with gender, age, calcification, and Hashimoto's disease and correlated to TNM stage $(P=0.009)$ and LNM $(P=0.037)$. However, there is a significant association between tumor size and HIF- $2 \alpha(P=0.035)$. To date, there is no report about tumor size like ours. It is necessary to further explore the mechanisms. So far, our data confirm the role of HIF-2 $\alpha$ in the tumor progression of PTC.

Interestingly, this study demonstrated a significantly positive correlation between HIF- $1 \alpha$ and HIF- $2 \alpha$ protein expression in PTCs for the first time. HIF- $1 \alpha$ expression is positively associated with HIF- $2 \alpha$ expression $(P=0.034)$.To date, there was no study could explain this positive correlation in PTCs. It is necessary for us to explore mechanisms underlying this correlation.

Besides HIF- $1 \alpha$ and HIF- $2 \alpha$, the other hypoxia family members, HIF-3 $\alpha$ for instance, are also involved in cellular responses to hypoxia. HIF- $3 \alpha$ has an ability to compete with HIF- $1 \alpha$ and HIF- $2 \alpha$ to bind with HIF- $1 \beta$ subunits, reducing the levels of HIF-1 and HIF-2, thereby inhibiting the up-regulation of target gene expression induced by HIF-1 and HIF-2 [34]. So, it may also be involved in the development and progression of PTC, and we need to 
conduct more extensive studies to understand the roles they play in this progress.

This study compares the expression of HIF- $1 \alpha$ and HIF- $2 \alpha$ in PTCs and normal tissues separately at the level of gene and protein. To our knowledge, it is the first time to demonstrate the significantly positive correlation between HIF- $1 \alpha$ and HIF- $2 \alpha$ protein expression in PTCs. However, in the present study, it mainly focuses on tissues. Much more extensive studies about mechanisms at the cellular and molecular levels would be needed in the coming future.

\section{Conclusions}

To our knowledge, this is the first study that demonstrates the positive correlation between HIF- $1 \alpha$ and HIF- $2 \alpha$ in PTCs. High expression of HIF- $1 \alpha$ and HIF- $2 \alpha$ was associated with high TNM stage and LNM. Consequently, our results provide a possible basis for prediction of LNM and progression in PTC and may provide new therapeutic options targeting hypoxia-associated and hypoxia-regulated proteins. However, the underlying mechanisms still need further exploration, and future studies in larger sets of patients will be necessary to determine the utility of these molecules as biomarkers of tumor diagnosis and prognosis in PTC.

\section{Abbreviations}

ARNT: arylhydrocarbon receptor nuclear translocator; bHLH: basic helix-loop-helix; CT: cycle threshold; GAPDH: glyceraldehyde-3-phosphate dehydrogenase; HIF: hypoxia-inducible factor; IHC: immunohistochemistry; PAS: per-amt-sim; PTC: papillary thyroid carcinoma.

\section{Competing interests}

The authors declare that they have no competing interests.

\section{Authors' contributions}

YML designed the research. YML, SPY, YRH, YP, WJC, LQN, JYX, and QYS conducted the experiment. YML and SPY analyzed the data. YML wrote the paper. All authors read and approved the final manuscript.

\section{Acknowledgements}

Thanks to my teacher Mr. Liang for the guide. Thanks to my classmates and colleagues for the help.

\section{Author details}

'Department of Radiation Oncology, Taizhou Central Hospital, Taizhou 318000, Zhejiang, China. ${ }^{2}$ Taizhou University, Taizhou 318000, Zhejiang, China. ${ }^{3}$ Department of Breast and Thyroid Surgery, Taizhou Central Hospital, Taizhou 318000, Zhejiang, China. ${ }^{4}$ Department of Breast and Thyroid Surgery, Taizhou Municipal Hospital, Taizhou 318000, Zhejiang, China. ${ }^{5}$ Department of Wenzhou Medical University, Wenzhou 325000, Zhejiang, China.

${ }^{6}$ Department of The First Affiliated Hospital of Wenzhou Medical University, Wenzhou 325000, Zhejiang, China.

Received: 2 September 2015 Accepted: 27 January 2016

Published online: 04 February 2016

\section{References}

1. Du LB, Li HZ, Wang XH, Zhu C, Liu QM, Li QL, et al. Analysis of cancer incidence in Zhejiang cancer registry in China during 2000 to 2009. Asian Pac J Cancer Prev. 2014;15:5839-43.

2. Cooper DS, Doherty GM, Haugen BR, Kloos RT, Lee SL, Mandel SJ, et al. Revised American Thyroid Association management guidelines for patients with thyroid nodules and differentiated thyroid cancer. Thyroid. 2009;19: 1167-74.

3. Cancer facts \& figures 2012. Atlanta: American Cancer Society. http://www cancer.org/acs/groups/content/@epidemiologysurveilance/documents/ document/acspc-031941.pdf. [Accessed 5 February 2014].

4. Rotstein $L$. The role of lymphadenectomy in the management of papillary carcinoma of the thyroid. J Surg Oncol. 2009;99:186-8.

5. Brahimi-Horn MC, Chiche J, Pouyssegur J. Hypoxia and cancer. J Mol Med. 2007;85:1301-7.

6. Semenza GL. Involvement of hypoxia-inducible factor 1 in human cancer. Intern Med. 2002;41:79-83.

7. Ke Q, Costa M. Hypoxia-inducible factor-1 (HIF-1). Mol Pharmacol. 2006;70:1469-80.

8. Gort EH, Groot AJ. vander Wall E, van Diest PJ, Vooijs MA. Hypoxic regulation of metastasis via hypoxia-inducible factors. Curr Mol Med. 2008:8:60-7.

9. Fong $\mathrm{GH}$, Takeda K. Role and regulation of proly hydroxylase domain proteins. Cell Death Differ. 2008;15:635-41.

10. Majmundar AJ, Wong WJ, Simon MC. Hypoxia-inducible factors and the response to hypoxic stress. Mol Cell. 2010;40:294-309.

11. Patel SA, Simon MC. Biology of hypoxia-inducible factor-2a in development and disease. Cell Death Differ. 2008;15:628-34.

12. Loboda A, Jozkowicz A, Dulak J. HIF-1 and HIF-2 transcription factors_similar but not identical. Mol Cell. 2010;29:435-42.

13. Covello KL, Simon MC, Keith B. Targeted replacement of hypoxia-inducible factor-1alphaby a hypoxia-inducible factor-2alpha knock-in allele promotes tumor growth. Cancer Res. 2005, 65(6): 2277-86.

14. Evens AM, Schumacker PT, Helenowski IB, Singh AT, Dokic D, Keswani A, et al. Hypoxia inducible factor-alpha activation in lymphoma and relationship to the thioredoxin family. Br J Haematol. 2008;141:676-80.

15. Osada R, Horiuchi A, Kikuchi N, Yoshida J, Hayashi A, Ota M, et al. Expression of hypoxia-inducible factor 1alpha, hypoxia-inducible factor 1alpha, hypoxiainducible factor 2alpha, and von Hippel-Lindau protein in epithelial ovarian neoplasm sandal lelic loss of vonHippel-Lindaugene: nuclear expression of hypoxia-inducible factor 1alpha is an independent prognostic factor in ovarian carcinoma. Hum Pathol. 2007;38:1310-20.

16. Winter SC, Shah KA, Han C, Campo L, Turley H, Marnane C, et al. The relation between hypoxia-inducible factor (HIF)-1alpha and HIF-2alpha expression with anemia and outcome in surgically treated head and neck cancer. Cancer. 2006:107:757-66.

17. Bertout JA, Majmundar AJ, Gordan JD, Lam JC, Ditsworth D, Keith B, et al. HIF2 alpha inhibition promotes p53 pathway activity, tumor cell death, and radiation responses. Proc Natl Acad Sci U S A. 2009;106:14391-6.

18. Yang SL, Liu LP, Jiang JX, Xiong ZF, He QJ, Wu C, et al. The correlation of expression levels of HIF-1a and HIF-2a in hepatocellular carcinoma with capsular invasion, portal vein tumor thrombi and patients' clinical outcome. Jpn J Clin Oncol. 2014:44:159-67.

19. Sobin L, Gospodarowicz M, Wittekind C. TNM classification of malignant tumours. New York: Wiley-Blackwell; 2009.

20. Harris AL. Hupoxia: a key regulatory factor in tumor growth. Nat Rev Cancer. 2002;2:38-47.

21. Keith B, Johnson RS, Simon MC. HIF-1a and 2a: sibling rivalry in hypoxic tumour growth and progression. Nat Rev Cancer. 2012;12:9-22.

22. Shen C, Beroukhim R, Schumacher SE, Zhou J, Chang M, Signoretti S, et al. Genetic and functional studies implicate HIF1alpha as a 14q kidney cancer suppressor gene. Cancer Discov. 2011;1:222-35.

23. Lu X, Kang Y. Hypoxia and hypoxia-inducible factors: master regulators of metastasis. Clin Cancer Res. 2010;16:5928-35.

24. Eckschlager T, Adam V, Hrabeta J, Figova K, Kizek R. Metallothioneins and cancer. Curr Protein Pept Sci. 2009;10:360-75.

25. Alves CC, Carneiro F, Hoefler H, Becker KF. Role of the epithelialmesenchymal transition regulator Slug in primary human cancers. Front Biosci (Landmark Ed). 2009;14:3035-50.

26. Storci G, Sansone P, Trere D, Tavolari S, Taffurelli M, Ceccarelli C, et al. The basal-like breast carcinoma phenotype is regulated by SLUG gene expression. J Pathol. 2008:214:25-37.

27. Koperek O, Akin E, Asari R, Niederle B, Neuhold N. Expression of hypoxiainducible factor 1 alpha in papillary thyroid carcinoma is associated with desmoplastic stromal reaction and lymph node metastasis. Virchows Arch. 2013:463:795-802.

28. Wang N, Luo HJ, Yin GB, Dong CR, Xu M, Chen GG, et al. Overexpression of HIF-2a, TWIST, and CXCR4 is associated with lymph node metastasis in papillary thyroid carcinoma. Clin Dev Immunol. 2013;2013:589423. 
29. Semenza GL, Wang GL. A nuclear factor induced by hypoxiavia de novo protein synthesis binds to the human erythropoietin gene enhancer at a site required for transcriptional activation. Mol Cell Biol. 1992;12:5447-54.

30. Wang GL, Semenza GL. Characterization of hypoxia-inducible factor 1 and regulation of DNA binding activity by hypoxia. J Biol Chem. 1993;268:21513-18.

31. Valencak J, Kittler H, Schmid K, Schreiber M, Raderer M, GonzalezInchaurraga $\mathrm{M}$, et al. Prognostic relevance of hypoxia inducible factor1alpha expression in patients with melanoma. Clin Exp Dermatol. 2009;34: 962-4.

32. Toschi A, Lee E, Gadir N, Ohh M, Foster DA. Differential dependence of hypoxia-inducible factors 1 alpha and 2 alpha on mTORC 1 and mTORC2. J Biol Chem. 2008;283:34495-9.

33. Xue $X$, Shah YM. Hypoxia-inducible factor-2a is essential in activating the COX2/mPGES-1/PGE2 signaling axis in colon cancer. Carcinogenesis. 2013;34:163-9

34. Hara S, Hamada J, Kobayashi C, Kondo Y, Imura N. Expression and characterization of hypoxia-inducible factor (HIF)-3alpha in human kidney: suppression of HIF-mediated gene expression by HIF-3alpha. Biochem Biophys Res Commun. 2001;287:808-13.

Submit your next manuscript to BioMed Central and we will help you at every step:

- We accept pre-submission inquiries

- Our selector tool helps you to find the most relevant journal

- We provide round the clock customer support

- Convenient online submission

- Thorough peer review

- Inclusion in PubMed and all major indexing services

- Maximum visibility for your research

Submit your manuscript at www.biomedcentral.com/submit
Biomed Central 